\title{
Experimental-Based Scientific Approach toward the improvement of Science Process Skill and Scientific Attitudes of Grade X Student MAN Ende
}

\author{
Melkyanus Kaleka ${ }^{1 *}$, Fara Dillah M. Nur ${ }^{2}$ \\ ${ }^{1,2}$ Physic Study Program, Flores University \\ Corresponding Author. Email: eka.umbu@yahoo.co.id
}

Keywords:
Scientific
Approach,
Experimental,
Science Process
Skill, and Scientific
Attitude.

Keywords:

Approach,

Experimental

Skill, and Scientific

Attitude.

\begin{abstract}
This study aimed to: 1) know the influence of the implementation of experimental-based scientific approach on physic learning toward the improvement of Science Process Skill of class X student of MAN Ende on even semester of academic year 2016/2017, 2) know the influence of the implementation of experimental-based scientific approach on physics learning toward the improvement of scientific attitude of class X student of MAN Ende on even semester of academic year 2016/2017. The research type is experimental research with the pre-experimental design and one-shot case study model. The population of the study was students of class X IPA MAN Ende which had the total of 136 students, and the sample of research was 30 students by purposive sampling technique. The data of the research sample is the score of science process skills and students' scientific attitude. T-test of one sample was used in data analysis. The research results showed that: 1) Implementation of experimental-based scientific approach on physics learning has effect to the improvement of students science process skills of class X student of MAN Ende on even semester of academic year 2016/2017, due to the normality test using chi-square test obtained $\chi^{2}$ count $(4.536)<\chi^{2}$ table (7.814), and result of data analysis on hypothesis test is obtained t-count (2.702) > t_table (1.699). 2) Implementation of experimental-based scientific approach on physics learning has effect to the improvement of science attitude of class $X$ student of MAN Ende on even semester of academic year $2016 / 2017$, due to by $\chi^{2}$ count $(4.503)<\chi^{2}$ table (7.814) and t_count (8.031) > t_table (1.699) on $\alpha=5 \%, \mathrm{dk}=29$.
\end{abstract}

C2018 JSER. Yogyakarta State University.

\section{INTRODUCTION}

Science teaching in Indonesia today tends to emphasize on product aspect which is dominated by facts, law and theory. And then, process and attitude aspects have less portion of attention. Particular in the physics learning, students are forced with a number of formulas and mathematical equations that must be memorized by the students, and the goal, students are able to answer the questions. In fact, students often do not understand the meaning of mathematical notation of a law of physics. Teachers rarely conduct laboratory learning, but teachers tend to use lecture methods in learning (E. Rahayu, et al. 2011). The learning process has not been optimal because students have not actively in the teaching learning process. Students only sit quietly and listen to the material from the teacher (I. Kd. Urip Astika, et al, 2013)
Based on the observations in the State Aliyah Madrasah (MAN) Ende, the school has implemented the 2013 curriculum. It found facts during the physics teaching learning process, the teachers has less facilitated the students to develop the science process, such as in observing the object directly. In addition, learning what happened today just transferring knowledge to students, and still centered on the teacher (Sukardiyono \& Rosana, 2017). This leads to not getting the experience to understand the concept in full by the student. And then, in the learning process, teacher mostly only explains the material that not leads to student-centered learning, and it makes the students become less active and less able in the science process skills. 
In addition, based on the results of interviews with physics teacher class $X$, it found that the students' scientific attitude is still low, such the domain of curiosity. Lack of students' curiosity is indicated by the number of students who asks questions, opinions, or answers the questions in the teaching process. The questions that asked by students are only limited to formulas or problems related to the material being studied. Students rarely ask the teacher about the relationship between the events in environment and the physics. As the result of both the students' lack of process skills and the low of scientific attitudes, it has impact to the dissatisfy achievement of physics learning of student class $\mathrm{X}$. The fact is appropriate to the results of research conducted by Munahamad Rizal, shows that the skills of the science process correlate with the mastery of the concept that leads to learning achievement (Rizal, 2014).

In the development of the 2013 curriculum, it is recommended to use scientific approach. Scientific approach based on exercise of science process skills includes of observing, questioning, collecting information / trying, reasoning / associating, and communicating (5M) (Ministry of Education regulation / Permendikbud No. 103, 2014: 3). Scientific approach is a learning approach that gives opportunities to students in exploring and elaborating the material. Moreover, the scientific approach also provides opportunities to students in actualizing their abilities through learning activities that have been designed by the teachers (Rusman, 2015: 232).

The scientific approach is perceived as a golden tool for the development, and develops the students' attitudes, skills and knowledge. Through the scientific approach, students may think scientifically and creatively in the learning. Scientific learning not only monitors the learning outcomes as the final, but also the learning process is considered as very important thing. Therefore, the scientific learning emphasizes on the process of skills. Scientific learning model based on the improvement of science process skill is a learning model that integrates the science process skills into an integrated system of material presentation.

According to Trianto (in Prabawaty, 2015: 1), the science process skill is the whole of directed scientific skill (both cognitive and psychomotor) that can be used to find a concept or principle or theory to develop a pre-existing concept, or deny an invention. The skills of the science process should be trained to students in order to create a scientific spirit in students, and then, it may apply in everyday life.
According to Rustaman (in Hilpan, 2014: 24), process skills are skills involving of cognitive or intellectual, manual, and social. Harlen (in Hilpan, 2014) defines the scientific process skills as the skills that commonly used by scientists to obtain knowledge. Based on the previous definitions, it may conclude the definition of science process skills in learning is a skill or ability / physical proficiency and mental that must be possessed by students in a science learning process, as the result, they are able to find knowledge, concept, principle, theory, law, and fact.

The following are some definition of the science process skills by Harlen that become focus of the research, they are:

1) Questioning Skills; are the basic skills that must be possessed by students before they discuss a problem. The questions may be in asking for clarification about what, why, and how, or ask for the background of hypothesis.

2) Hypothetical skills; the hypothesis is a reasonable approximation to explain a particular event or observation. The hypothetical skill is a skill in formulating a theory or opinion that is considered as true, or the truth need to be proven.

3) Skills in Using Tools and Materials; In the goal of having the skills of using tools and materials, students must directly use the tools and materials in order to gain hands-on experience. In addition, students must understand the why and how to use tools and materials.

4) Skills of planning to Experiment or investigation; the skill type are skills in determining the tools and materials, determining the variables in an experiment, determining the control variables and independent variables, determining of what is observed, measured, or written, and determining of how to work and how to process the data.

5) Observation Skill; the skill is related to the optimal and proportional use of all the sensor devices to describe the object and time-space relationships or measure the characteristics of the observed objects. Observation skills include of using the sense of sight, smell, listener, taste and touch in observing the characteristics of an object and using relevant facts and adequate based on the observation result. Thus, it may collect relevant and adequate facts independently.

6) Interpretation Skills (inferring); Interpretation skills include the skills of recording the observations result, connecting the observations 
result, and finding the patterns of order from one series of observations into a conclusion.

7) Communication Skills; are Informing the observation result, results of predictions or experimental to others including communication skills. The form of the communication may be in the speech and written. The type of communication may be in a systematic exposure (report) or partial transformation. Communication skills include of the ability to read the graphs, tables or diagrams.

Scientific attitude is an attitude that must exist in a scientist or academician when faced scientific problems. Scientific attitudes in science learning are often associated with attitudes toward science. The emergence of scientific attitudes during the learning process is very good, because there is a positive correlation between process skills and scientific attitudes (Muhammad Rizal, 2014). Scientific attitude is distinguished from mere attitude toward science due to attitudes toward science focus only on whether students like or dislike the learning of science, while scientific attitudes include others scientific characteristic such as honesty, open minded, and curiosity (Fatonah and Prasetyo, 2014: 29-30).

Table 1.1 Clustering of Scientific Attitudes

\begin{tabular}{lll}
\hline Gegga (1977) & Harlen (1996) & AAAS (1993) \\
\hline Curiosity & Curiosity & Curiosity \\
Inventiveness & Respect for evidence & Honesty \\
Critical thinking & Critical reflection & Open minded \\
Persistence & Perseverance & Skepticism \\
& Creativity and inventiveness & \\
& Open mindedness & \\
& Creativity and inventiveness & \\
& Open mindedness & \\
& Cooperation with others & \\
& Willingness to tolerate uncertainty & \\
& Sensitivity to environment & \\
\hline
\end{tabular}

Table 1.2 Dimensions and Indicators of Scientific Attitude by Harlen

\begin{tabular}{|c|c|c|}
\hline No. & Dimensions & Indicators \\
\hline 1 & Curiosity & $\begin{array}{l}\text { Enthusiastic in looking for answers. } \\
\text { Attention to the object being observed. } \\
\text { Enthusiastic on the Science process. } \\
\text { Ask to every step of the activity. }\end{array}$ \\
\hline 2 & $\begin{array}{l}\text { Respect to } \\
\text { Data/Fact }\end{array}$ & $\begin{array}{l}\text { Objective / honesty } \\
\text { No manipulate the data. } \\
\text { No prejudice. } \\
\text { Make decisions based on facts. } \\
\text { No blend between facts and opinions. }\end{array}$ \\
\hline 3 & $\begin{array}{l}\text { Critical } \\
\text { Thinking }\end{array}$ & $\begin{array}{l}\text { Doubt the friends' findings. } \\
\text { Critic to every new change / invention. } \\
\text { Repeat the performed activities. } \\
\text { No ignore the data. }\end{array}$ \\
\hline 4 & $\begin{array}{l}\text { Inventiveness } \\
\text { and Creativity }\end{array}$ & $\begin{array}{l}\text { Using facts for the basis of conclusions. } \\
\text { Show different reports with classmates. } \\
\text { Change the opinion in response to facts. } \\
\text { Using the tool is not as usual } \\
\text { Suggest new experiments. } \\
\text { Outlining the new conclusions of observations. }\end{array}$ \\
\hline 5 & $\begin{array}{l}\text { Open Minded } \\
\text { and } \\
\text { Cooperation } \\
\text { with others }\end{array}$ & $\begin{array}{l}\text { Respect the opinion / findings of others. } \\
\text { Want to change opinion if the data is less. } \\
\text { Receive the advice from others. } \\
\text { No have feeling that always right. }\end{array}$ \\
\hline
\end{tabular}




\begin{tabular}{lll}
\hline & $\begin{array}{l}\text { Assuming each conclusion is tentative. } \\
\text { Participate actively in groups. } \\
\text { Continue the research after the "novelty" is gone. } \\
\text { Repeating the experiment even though the experiment } \\
\text { is failure. } \\
\text { Complete an activity though friends. } \\
\text { The class finished early. }\end{array}$ \\
$7 \quad$ Sensitivity to & $\begin{array}{l}\text { Attention to surrounding events. } \\
\text { environment } \\
\text { Participation in social activities. } \\
\text { Maintain the cleanliness of the school environment. }\end{array}$ \\
\hline
\end{tabular}

The clustering of scientific attitudes by experts is varies considerably, although when there further examined, there is almost no significant difference among them. Variations appear only in the placement and naming of scientific attitudes that are highlighted. For example, clustering by Gegga (1997), Harlen (1996), and American Association for Advancement of Science (AAAS) 1993, is summarized in Table 1.1 (Fatonah and Prasetyo, 2014: 30-32).

Meanwhile, the following are clustering of scientific attitudes dimension developed by Harlen (1996) and its indicator (in Fatonah and Prasetyo, 2014, 32-34). The research result by Parno S.

This research was experimental research with quantitative approach. The research design in the research was pre experimental design with oneshot case study model, because in the research there are also external variables that influence (there is no control variable) and the sample is not selected randomly (Sugiyono, 2012: 109). The research was conducted at State Aliyah Madrasah (MAN) Ende, which has been conducted for five months from February to July 2017.

The population of the research is all students of class X IPA on even semester MAN Ende academic year 2016/2017 consisting of 4 classes with 136 students. The sample of the research is the students of class X IPA 4 and the total of students is 30 students. Purposive sampling was used to determine the samples of the research.

Data collection techniques of the study included of:

1) Observation

In the research, the focus object of the research was the students. Student activity was observed directly during the learning activities. The scientific process skill observation sheet (KPS) in the research consisted of five science process skills including; observing, composing hypotheses, experimenting, concluding and communicating.

2) Questionnaire

The sheets of questionnaire in the study were used to collect data on students' scientific
Mahulae, et al (2017), indicates that the application of science process skill has an effect on the high average of students' scientific attitude score. Johari Marjan's (2014) research result shows that learning of scientific approach is better than direct learning model in improving biology learning outcomes and science process skills. The research results of Afif $\mathrm{Hafez}$ and Majdi indicate that there is a significant correlation between the level of knowledge of science process skills and the attitude of science toward science (2015).

\section{METHOD}

attitudes. Scale measurements were based on the likert scale: strongly agree (SS), agree (S), hesitate (RR), Disagree (TS), and strongly disagree (STS).

3) Documentation

Collected documentation data was data that related to activities during the learning.

The prerequisite test performed in the research was a normality test by chi-square technique. The normality test was performed to prove that the population in the study has normal distribution. The equation (Sugiyono, 2012: 241):

Where:

$$
\chi^{2}=\sum\left[\frac{\left(f_{0}-f_{h}\right)^{2}}{f_{t}}\right]
$$

$\chi^{2}=$ Score of chi-square

$f_{h}=$ Observed frequency

$f_{e}=$ Expected frequency

If the calculated chi-square score is less than or equal to the chi-square score of the table $\left(\chi^{2}\right.$ _count $\leq \chi^{2}$ _table $)$, then the data distribution is normal with the real level $(\alpha=0.05)$, and $\mathrm{dk}=\mathrm{k}$ 3 . The two-point equality test or the right-hand test was used to test the hypothesis, with the steps; Hypothesis 1

$H_{0}$ : $<75$; meaning that the implementation of experimental-based scientific approach toward physics learning has no effect in improving the students' science process skills of class $X$ student of MAN Ende on even semester of academic year 2016/2017. 
$H_{a 1}: \quad \geq 75$; meaning that the implementation of experimental-based scientific approach toward physics learning has effect in improving the students' science process skills of class $\mathrm{X}$ student of MAN Ende on even semester of academic year 2016/2017.

\section{Average Score of Science Process Skill}

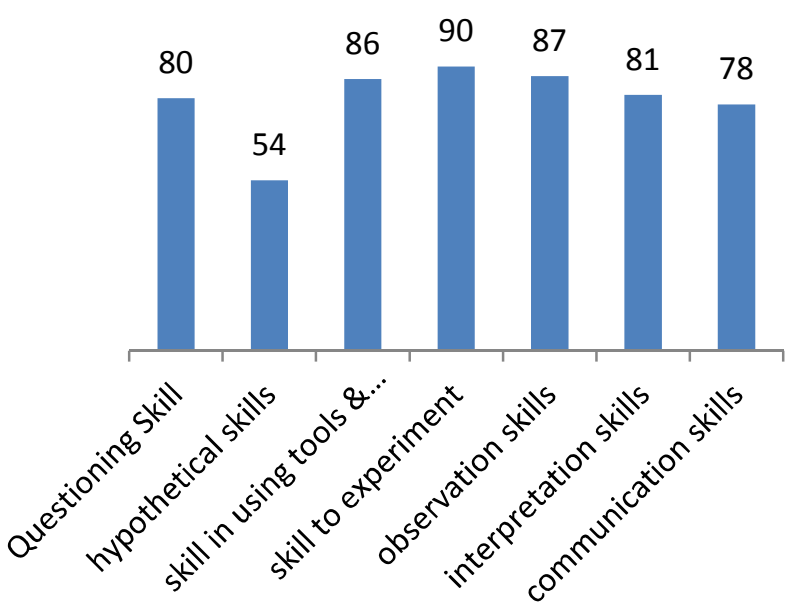

Diagram 1.1 Diagram of level of science process skill

\section{Hypothesis 2}

$H_{0}: \quad<75$; meaning that the implementation of experimental-based scientific approach toward physics learning has no effect in improving the students' science attitudes of class $\mathrm{X}$ student of MAN Ende on even semester of academic year 2016/2017.

$H_{a 2}$ : $\geq 75$; meaning that the implementation of experimental-based scientific approach toward physics learning has effect in improving the students' science attitudes of class X student of MAN Ende on even semester of academic year 2016/2017.

Significant level $(\alpha)=0,05$.

Degree of freedom $d k=n-1$.

\section{Statistic of Test}

One sample t-test was used as statistic of test, with the formula:

$$
\mathrm{t}=\frac{\bar{x}-\mu_{0}}{s / \sqrt{n}}
$$

\section{RESULTS}

\section{Science Process Skills}

The data of science process skills was obtained from the observation sheet. The observation sheets were based on seven dimensions of science process skills; questioning skills, hypothetical skills, skill in using tools \& materials, skill to experiment, observation skills, interpretation skills, and communication skills.

The level of science process skills acquired by student grade X IPA MAN Ende on even semester of academic year 2016/2017 based on average score is presented in diagram 1.1.

The learning process using scientific approach is designed in order the students actively construct the concepts, laws or principles through the steps of observing, formulating problems, proposing or formulating hypotheses, collecting data, analyzing data, making conclusions and communicating the concepts, laws, and principles. In the scientific approach, the competence of attitudes, skills, and knowledge may be accommodated by scientific activities involving of scientific processes, scientific attitudes, and scientific products.

The implementation of specific approach in learning integrates the science process skills in the process of learning. Scientific process skills (scientific processes) that measured in the research are questioning skills, hypotheses skill, skill in using tools and materials, skill to experiment, observation skill, interpretation skills and communication skills. Those skills are trained in scientific approach.

In the study, students were given treatment of an experimental-based scientific approach in the learning. The experimental method is a teaching method where the student do experiments by proving something in the learning. In the research 
process, the instrument is observation sheets of science process skill. Observations was conducted by observe the successful implementation of learning process and student activities.

The steps of activity during the research conducted implementation of experimental-based scientific approach, the steps of:

a) Observing

In observing activities, the teacher delivers learning material about the simple harmonic motion in outline to the students. Students observe when the teacher explains the material by demonstrating the vibration on a simple pendulum swing. At this step, teachers may assess the skills of the science process in the term of observing skills.

b) Questioning

After the teacher explains the learning materials, the teacher provides an opportunity to students to deliver questions about what happened in the demonstration that has been conducted, and the explanation of the learning materials that have not been understood. At this step, the teacher may assess the students' science process skills in the term of questioning skills.

c) Collecting Information

At this step, the students are divided into five groups consisting of 7 students. The step of collecting information is conducted by experimental activities about simple pendulum swings. Teachers distribute the Student Worksheets (LKS) to each group. During experimental activities, teachers may observe and assess the students' science process skills in the term of questioning, hypothetical skills, using tools and materials, do the experiments, and observations.

d) Reasoning / associating

After the experimental activity, the next step is the reasoning / associating where the students manage / analyze the results of observations \& experiments. In addition, the teachers guide the students who have difficulty in analyzing the data. At this step, teachers may assess the students' science process skills in the term of skills of questioning, hypothetical skills, and interpreting data (concluding).

e) Communicating

The final step of implementing a scientific approach is communicating. The teacher provides an opportunity to each group to present the discussion results of the experiment. At this step, teachers may assess the students' science process skills in terms of communicating skills.

Based on the research observation, the students are very active and enthusiastic in the learning process that implement of experimentalbased scientific approach. It is proved by the calculation of the average score of the seventh dimension of students' science process skills is 79 or in category of good enough. Based on Figure 4.1 , the highest average score of students' science process skill is the skill of experimenting with the average score is 90 . In contrast, the lowest score of the students' science process skill is hypothetical skills with the average score is 54 . It based on during the research activity, the students are still not able to propose a hypothesis correctly. The analysis result of t-test one sample by using determinant of minimal criteria is 75 , obtained t_count $(2,702)>$ t_tabel $(1,699)$. It may conclude that the implementation of experimental-based scientific approach toward physics learning has effect in improving the students' science process skills of class $\mathrm{X}$ student of MAN Ende on even semester of academic year 2016/2017.

\section{Science Attitudes}

The level of science attitudes acquired by student grade X IPA MAN Ende on even semester of academic year 2016/2017 based on average score is presented in diagram 1.2 
Average Score of Science Attitudes

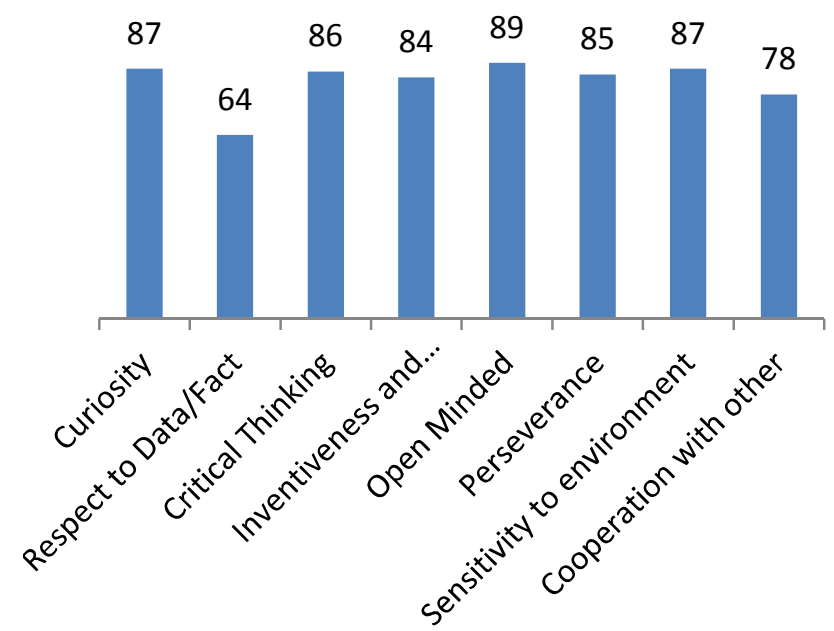

Diagram 1.2 Diagram of level of science attitudes

The level of students' success in learning is strongly influenced by several factors that must be considered including of the approaches and learning methods. The successful learning is not only based on the cognitive aspect but also the affective aspects associated with attitude. In the scientific approach, attitude competence may be accommodated by the scientific activities to elicit students' scientific attitude. In this research, researchers implement experimental-based scientific approach in the teaching process by way divided in groups, in order, the learning process facilitate the students to share opinions and cooperation with others, and will lead to interaction and scientific attitude.

Scientific attitude is an attitude that must exist in a scientist or academician when faced scientific problems. By the scientific approach, the observation activity is very useful for the students' curiosity need and making the learning process has positive effect to student. Moreover, through the step of questioning, it may encourage the students' scientific attitudes such as curiosity and critical thinking.

Based on the research results, from the questionnaire of students' scientific attitudes which are 30 statements, obtained the average score for each dimension of scientific attitude. The highest score is on the dimensions of open-minded attitude, and the lowest average score of the scientific attitudes is respect to data. Moreover, in the dimensions of curiosity and sensitive to environment obtained an average score of 87 . The score may also categorize as very good, and proved when during learning process students are very active to question of confuse / do not understand material. The dimension of critical thinking obtained an average score of 86. And then, dimension of persistence, and inventiveness attitude and creativity obtained an average score of 85 and 84. In the cooperative attitude dimension obtained an average score of 78 . By the average scores of eighth dimensions of scientific attitudes, the scientific attitudes acquired by students of class X IPA MAN Ende may categorize as very good, it is proved by the average score of the overall dimensions of students' scientific attitude is 82.5.

The analysis result of t-test one sample by using determinant of minimal mastery is 75, obtained t_count > t_table with score 8,031> 1,699. It may conclude that the implementation of experimental-based scientific approach toward physics learning has effects in improving the students' scientific attitude of class X student of MAN Ende on even semester of academic year 2016/2017.

\section{CONCLUSION}

Based on the results of data analysis and discussion, concluded: 1) Implementation of experimental-based scientific approach toward physics learning has effect in improving the students' science process skills of class X student of MAN Ende on even semester of academic year $2016 / 2017$. It is proved by normality test using chi-square test obtained $\chi^{2}$ _count $(4.536)<$ $\chi^{2}$ table (7.814) and data analysis result of hypothesis test obtained t_count (2.702) > t_table (1.699) at $\alpha=0.05$ and $\mathrm{dk}=29 ; 2$ ). Implementation of experimental-based scientific approach toward physics learning has effect in improving the students' scientific attitude of class $\mathrm{X}$ student of MAN Ende on even semester of 
academic year 2016/2017. It is proved by normality test using chi-square test obtained $\chi^{2}$ _count $(4.503)<\chi^{2}$ table (7.814) and data analysis result of hypothesis test obtained t_count (8.031) > t_table (1.699) at $\alpha=0.05$ and $\mathrm{dk}=29$.

\section{REFERENCES}

Afif Hafez Zeidan \& Majdi Rashed Jayosi, (2014). Science Process Skills and Attitudes toward Science among Palestinian Secondary School Students. Journal (Word Journal of Education). Vol. 5, N0. 1; 2014, p13).

E. Rahayu, H. Susanto, D. Yulianti. (2011). Pembelajaran Sains dengan Pendekatan Keterampilan Proses untuk Meningkatkan Hasil Belajar dan Kemampuan Berpikir Kreatif Siswa. Jurnal Pendidikan Fisika Indonesia, ISSN: 1693-1246 hal 106-110.

Fatonah, Siti \& Prasetyo, K. Zuhdan. (2014). Pembelajaran Sains. Penerbit Ombak: Yogyakarta.

Hilpan, Mochamad. (2014). Analisis Ketersediaan Keterampilan Proses Sains (KPS) dalam Buku Sekolah Elektronik (BSE) Fisika Kelas XI pada Konsep Fluida. (Pdf) Jakarta: skripsi UIN Syarif Hidayatullah.

I. Kd. Urip Astika, I.K. Suma, I. W. Suastra. (2013). Pengaruh Model Pembelajaran Berbasis Masalah Terhadap Sikap Ilmiah dan Keterampilan Berpikir Kritis. E-Journal Program Pascasarjana Universitas Pendidikan Ganesha Program Studi IPA (Volume 3).

Johari Marjan. (2014). Pengaruh Pembelajaran Pendekatan Saintifik Terhadap Hasil Belajar Biologi dan Keterampilan Proses Sains Siswa MA Mu'allimat NW Pancor Selong Kabupaten Lombok Timur Nusa Tenggara Barat. E-Journal Program Pascasarjana Universitas Pendidikan Ganesha Volume 4.

Muhammad Rizal, (2014). Pengaruh Pembelajaran Inkuiri Terbimbing dengan Multi Representasi terhadap Keterampilan Proses
Sains dan Penguasaan Konsep IPA Siswa SMP. Journal (Jurnal Pendidikan Sains) Volume2, Nomor 3, Halaman 159-165.

Parno S. Mahulae, Motlan Sirait, Makmur Sirait. (2017). The Effect of Inquiry Training Learning Model Using PhET Media and Scientific Attitude on Students' Science Process Skills. Journal (Journal of Research \& Method in Education IOSR-JRME). Volume 7, Issue 5 Ver. e-ISSN: 2320-7388, pISSN: 2320-737X. pp 24-29.

Permendikbud. (2014). Nomor 103 Tahun 2014 Tentang Pembelajaran pada PendidikanDasar dan Pendidikan Menengah.

Prabawati, Wahyu dan Rohandi. (2015). Keterampilan Proses Sains Guru IPA. Ejurnal Prosiding Pertemuan Ilmiah XXIX HFI Jateng \& DIY. Yogyakarta: Universitas Sanata Dharma.

Rizal, (2014). Pengaruh Pembelajaran Inkuiri Terbimbing dengan Multi Representasi terhadap Keterampilan Proses Sains dan Penguasan Konsep IPA Siswa SMP. Jurnal Pendidikan Sains. Vol. 2, No.3, September 2014, Hal 159 - 165.

Rusman. (2015). Pembelajaran Tematik Terpadu; Teori, Praktik dan Penilaian. Jakarta: Rajawali Pers.

Sugiyono. (2012). Metode Penelitian Pendidikan Pendekatan Kuantitatif, Kualitatif, dan R\&D. Bandung: Alfabeta.

Susilawati, Susilawati, dan Nyoman Sridana. (2015). Pengaruh Model Pembelajaran inkuri Terbimbing Terhadap Keterampilan Proses Sains Siswa. Jurnal Tadris IPA Biologi FITK IAIN Mataram. Volume VIII, Nomor 1.

Sukardiyono \& Dadan Rosana. (2017). Implementation of Integrated Science Instruction Assessment as an Alternative to Measure Science Process Skills and Social Attitudes. Journal of Science Education Research Vol $1, \quad$ No 1. 